\title{
Factors related to coffee quality, based on the "Cup of Excellence" contest in Mexico
}

\author{
Ana Laura Gumecindo-Alejo ${ }^{1}$ (D), Luz Amelia Sánchez-Landero' ${ }^{1}$, Gustavo Celestino Ortiz-Ceballos ${ }^{2}$ (D), \\ Carlos Roberto Cerdán-Cabrera² $\mathbb{D}$, Gerardo Alvarado-Castillo² $\mathbb{D}$
}

\author{
${ }^{1}$ Universidad Veracruzana/UV, Facultad de Ciencias Agrícolas-Xalapa/FCA-X, Xalapa, Veracruz, México \\ ${ }^{2}$ Universidad Veracruzana/UV, Posgrado en Ciencias Agropecuarias, Xalapa, Veracruz, México \\ Contact authors: lauragumecindo@hotmail.com, luzsanchez02@uv.mx, gusortiz@uv.mx, ccerdan@catie.ac.cr, gerardoalvaradoc@hotmail.com \\ Received in January 18, 2021 and approved in April 20, 2021
}

\section{ABSTRACT}

Coffee farming in Mexico is an activity of great economic, social, cultural, and environmental importance. One of the strategies for obtaining better prices is so-called "specialty coffees", whose quality is evaluated through the "cup of excellence" contest. The aim of this work was to identify if there are factors related to the quality of coffee, based on the data provided by this contest. Information was obtained for the period 2012 to 2019 (since the event was suspended in 2020), but given the heterogeneity in the data, exclusion, and inclusion criteria were applied, examining only the years 2017 to 2019. Descriptive analyses show that, in Mexico, the coffee producing states of Veracruz and Chiapas predominate the highest scores, possibly because they are regions with the highest presence of biodiversity, which favors the quality of the coffee. A simple linear regression model also noted that quantitative variables (altitude, temperature, and precipitation) do not affect cup quality. Finally, a square chi analysis showed that the factors that affect the score are the process and mixing of varieties, which establish differences in the sensory characteristics of coffee, observing dependence between the two. It is concluded that the latter influence the score, where the washing process is best suited for coffees with an extraordinary quality profile, as well as the use of one or three varieties (particularly Arabica type) and that environmental and site components do not have a decisive effect on coffee cup quality.

Index terms: Coffea arabica; coffee quality; score "cup of excellence" contest.

\section{INTRODUCTION}

Mexico is the tenth-largest coffee producer worldwide, supplying a quarter of market demand, and is the leading producer of organic coffee (Servicio de Información Agroalimentaria y Pesquera - SIAP, 2018). At the national level, coffee farming is a strategic activity for its economic, social, cultural, and environmental importance (Manson; Contreras; Lopez, 2008). However, the conditions of extensive production and small holder agriculture, together with low international prices (De Melo; Astorga, 2015), force producers to look for new strategies to increase their profitability. One of them is specialty coffee (differentiated product with outstanding quality attributes), which generates potential and opportunities to obtain better prices (Tolessa et al., 2016). This market, in broad growth (from $14 \%$ in 2001 to $41 \%$ in 2017 in the United States) (Ufer; Lin; Ortega, 2019), is the result of the demand of consumers who want unique attributes in the beverage (and are willing to pay more) (Peñuela-Martínez; Zapata-Zapata; DurangoRestrepo, 2018), so quality plays a fundamental role and is decisive in the future commercial value of production (Conley; Wilson, 2018; Abubakar et al., 2019), which can become up to six times the value of a traditional coffee (Oyola; Trujillo; Gutierrez, 2017).

Quality itself is a difficult concept to define, as it depends on various standards and market types, but in this case, it can be described as consumer satisfaction, by the outstanding characteristics and unique flavor profiles of coffee in the cup, compared to conventional standards (Oliveira et al., 2013, Ufer; Lin; Ortega, 2019). In such a way that the quality in a specialty coffee is the result of a large number of factors, involving characteristics of the producing region such as altitude, climate, and soils (Taveira et al., 2015; Toledo et al., 2016; Abubakar et al., 2019), agricultural practices (shadow, pruning, fertilization and varieties used) (Vaast et al., 2006), planting design and density (Dos Santos et al., 2018), maturity and uniformity in the harvest (Joët et al., 2010; Toledo et al., 2016; Peñuela-Martínez; Zapata-Zapata; Durango-Restrepo, 2018), processing (wet, dry or variants of these such as honey), storage conditions (Vaast et al., 2006), roasting (considered as one of the most important, since in this process the chemical properties of the coffee beans are modified, resulting in the taste and aroma of the beverage) (Abubakar et al., 2019; Rocha; Coqueiro; Valderrama, 2019; Dos Santos et al., 2018) and finally the preparation of the infusion (Craig et al., 2018; Giacalonea et al., 2019).

Consequently, the quality of a coffee cup and its distinctive sensory characteristics involve care throughout the production, processing, and storage chain (Oliveira et al., 2013; Sunarharum; Williams; Smyth, 2014; Abubakar et al., 2019). In this sense, the most widely used instrument to examine coffee quality is the sensory analysis which is based on the standards established by the Alliance for Coffee Excellence (Oliveira et al., 2013; Conley; Wilson, 2018; Sánchez et al., 2018). The evaluation is carried out through 
panels of trained tasters (Specialty Coffee Association of America - SCAA, 2015) that qualify on a scale of 0 to 10 , various attributes such as fragrance (dry smell)/aroma (smell of infusion) (Bressanello et al., 2017), flavor, aftertaste (astringency), acidity, body, balance, sweetness, clean cup, uniformity and defects, where a sum greater than 80 points will be considered as special coffee (Di Donfrancesco; Gutierrez; Chambers, 2014; Tolessa et al., 2016; Oyola; Trujillo; Gutierrez, 2017).

In Mexico, this evaluation takes on meaning through the "Cup of Excellence" contest that brings together national and international tasters, whose qualifications not only influence the selling price of qualified lots but favor the reputation of regions, producers, and marketers. In this sense, sensory analysis is equivalent to the use of any scientific instrument for measuring the characteristics associated with the quality of a food product (Feria, 2014) since there is homogeneity in the evaluation (Pereira et al., 2017). Therefore, this work aims to carry out an exploratory analysis to determine if there are environmental factors and processes related to coffee quality, based on the data provided by this competition.

\section{MATERIALS AND METHODS}

\subsection{Obtaining and processing data}

The information was obtained through the Asociación Mexicana de la Cadena Productiva del Café, A.C. (AMECAFE). which together with the Alliance for Coffee Excellence (ACE) is responsible for the development of the "Cup of Excellence" (COE) contest in Mexico. The procedure for obtaining the samples begins with a national call (you have to be a coffee producer and you can enter, at no cost, a sample, or two, with a payment of USD 250, if it's from a different coffee plantation). These will be $2 \mathrm{~kg}$ of goldtype coffee, representative of the harvest of the year, only of the Arabica type, and without additives that can alter its flavor. If selected in the first phase of cupping (Preselection), the lot must be delivered in a winery, in parchment coffee, ball, or "capulín" that, when converted into exportable green coffee or Gold, becomes a minimum amount of $210 \mathrm{~kg}$ but not greater than $1200 \mathrm{~kg}$. From there a representative sample of 6-7 kg of parchment coffee (washed and semi-washed process) or 9-10 kg the ball, or "capulín" (Natural process) will be taken. The grain must be flawless, with uniform size (maximum 20\% is allowed above and below grids sizes of number 16 to 18 ), no floats coffee, humidity from $9.5 \%$ to $12 \%$, and hydric activity no greater than 0.65 points.

Coffees with a score of 86 or more will move to the national jury phase. Here you can pass up to 150 samples, which will be identified to ensure traceability. These will be subjected to the second round of cupping, where coffees qualified with 86 points or more will go to the international jury phase (maximum of 40 samples). In the latter phase, scores greater than 87, go to an international auction (maximum of 30 coffees). To do this, it will be taken an estimated $18 \mathrm{~kg}$ of exportable green coffee for AMECAFE to send approximately 90 sets of samples to buyers, ACE members, and conduct an electronic auction, to finally do the maquila and export process, with the respective payment management for producers. The minimum selling price for cafes with scores of 85 to 86.99 (considered National

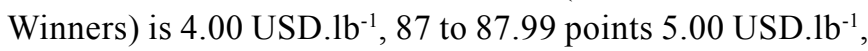
88 to 89.99 points $6.00 \mathrm{USD}^{-1 \mathrm{~b}^{-1}}$, and for 90 or more points 6.50 USD. $1 \mathrm{~b}^{-1}$ (the latter three are considered International Winners). Lots rated above 90 points (first three places) are divided in two so that they can be purchased by small roasters. In this case, buyers and producers will be able to make use of the COE logo, which entails prestige for sellers and reputation for producers (Asociación Mexicana de la Cadena Productiva del Café-AMECAFE, 2021).

The data obtained were from the period 2012 (when the event started) to 2019, with the exception of 2016, the year in which the competition was not held, and 2020 that was suspended because of the global pandemic. Great variability was observed in the information, so exclusion criteria (missing data, heterogeneity and incomplete information) and inclusion (common indicators, complete and uniform data) were applied in such a way that only the years 2017, 2018, and 2019 were chosen, which formed a database that was standardized in common factors: coffee producing states, variety mix, process, and altitude. The temperature and precipitation were obtained from the location of each winning farm, locating the nearest weather stations, and considering the climate standard from 1981 to 2010 (Comisión Nacional del Agua - CONAGUA, 2019). All the data were related to the score obtained in the cup (there are four categories: lower quality, very good, excellent, and extraordinary) established by the protocols of the contest, of which only two were determined: excellent (85-94.99 points) and extraordinary (95-100 points).

\subsection{Statistical analysis}

Due to the variability of the data considered for this work, different statistical methods were applied to determine whether these are related to coffee quality. For coffee producing states, a descriptive analysis was performed to determine trends relative to the sensory analysis score. For altitude, temperature, and precipitation, as quantitative data, a simple linear regression analysis was applied to know the degree of correlation with the score obtained in the contest. For mixing varieties and process (qualitative data) a correspondence analysis was applied in order to identify association patterns and groupings between them (with the above two dimensions 
were created and the percentage of inertia was obtained through a factorial analysis, in which the greater dependence between variables greater inertia, generating a diagram of a set of category points). The association between them was also sought through Cronbach's alpha analysis (represents confidence and consistency in the association of data from the variables analyzed), to finally apply a Chi-Square test, in order to specify the correlation between them. The Statistical Package for the Social Sciences (SPSS ${ }^{\circledR}$ ) was used for all analyses.

\section{RESULTS}

Although the "Cup of Excellence" contest has 20 years to be held worldwide, in Mexico only the seventh edition goes, so its recent creation has generated that the statistics are not homogeneous and the data and components involved are dispersed or in some cases absent, however, with the information obtained it can be seen that there are various factors involved in the quality of the coffee (Table 1). The first is the producing region, where, for example, the states of Veracruz and Chiapas show the highest scores of excellent and extraordinary qualities (Figure 1). It was also identified that statistically, the altitude $\left(\mathrm{R}^{2}=0.080\right)$, temperature $\left(\mathrm{R}^{2}=\right.$ $0.035)$, and precipitation $\left(\mathrm{R}^{2}=0.039\right)$, do not relate to the quality score in the cup. In contrast, the square chi test (value $=4.513$ ) indicates that the only factors that influence the score are the mix of varieties (Figure 2) and the process (Figure 3), which show dependence on each other (Cronbach alpha, average $=0.624)$ (Figure 4$)$.

Table 1: Characteristics of winners lots during the "Cup of Excellence" contest in Mexico.

\begin{tabular}{|c|c|c|c|c|c|c|c|}
\hline Year & Coffee producing states & Winners & Average score & Average price* & Variety** & Process & Average altitude \\
\hline \multirow{3}{*}{2012} & Chiapas & 5 & 87.45 & 8.71 & & & \\
\hline & Oaxaca & 1 & 88.21 & 7.2 & & & \\
\hline & Veracruz & 4 & 87.41 & 17.9 & & & \\
\hline \multirow{5}{*}{2013} & Chiapas & 4 & 87.66 & 9.75 & & & \\
\hline & Guerrero & 2 & 86.01 & 7.2 & & & \\
\hline & Oaxaca & 6 & 86.35 & 7.31 & & & \\
\hline & Puebla & 1 & 85.58 & 6.1 & & & \\
\hline & Veracruz & 3 & 88.21 & 22.76 & & & \\
\hline \multirow{3}{*}{2014} & Guerrero & 1 & 88.09 & 8.00 & & & \\
\hline & Oaxaca & 8 & 87.38 & 8.79 & & & \\
\hline & Veracruz & 10 & 88.35 & 9.87 & & & \\
\hline \multirow{4}{*}{2015} & Chiapas & 7 & 86.84 & 7.33 & & & \\
\hline & Oaxaca & 5 & 88.59 & 8 & & & \\
\hline & Puebla & 3 & 86.16 & 4.63 & & & \\
\hline & Veracruz & 5 & 88.9 & 11.7 & & & \\
\hline \multirow{4}{*}{2017} & Chiapas & 6 & 89.03 & 15.5 & $\begin{array}{c}\text { Bourbon }(46.1 \%) \\
\text { Caturra }(38.5 \%) \\
\text { Typica }(15.4 \%)\end{array}$ & $\begin{array}{l}\text { Washed }(83.3 \%) \\
\text { Natural }(16.7 \%)\end{array}$ & 1545 \\
\hline & Oaxaca & 5 & 88.18 & No data*** & $\begin{array}{c}\text { Bourbon }(30.0 \%) \\
\text { Mundo Novo }(30.0 \%) \\
\text { Typica }(30.0 \%) \\
\text { Caturra }(10.0 \%)\end{array}$ & Washed (100\%) & 1726 \\
\hline & Puebla & 2 & 87.68 & 8.7 & $\begin{array}{l}\text { Garnica }(66.6 \%) \\
\text { Bourbon }(33.4 \%)\end{array}$ & $\begin{array}{l}\text { Washed }(50.0 \%) \\
\text { Natural }(50.0 \%)\end{array}$ & 1200 \\
\hline & Veracruz & 14 & 89.15 & 19.64 & $\begin{array}{c}\text { Bourbon }(22.8 \%) \\
\text { Caturra }(22.8 \%) \\
\text { Typica }(22.8 \%) \\
\text { Garnica }(11.5 \%) \\
\text { Pacamara }(11.5 \%) \\
\text { Mundo Novo }(8.6 \%)\end{array}$ & Washed (100\%) & 1314 \\
\hline
\end{tabular}


Table 1: Continuation.

\begin{tabular}{|c|c|c|c|c|c|c|c|}
\hline Year & Coffee producing states & Winners & Average score & Average price* & Variety** & Process & Average altitude \\
\hline \multirow{6}{*}{2018} & Chiapas & 3 & 89.32 & 7.23 & $\begin{array}{c}\text { Bourbon }(25.0 \%) \\
\text { Typica }(25.0 \%) \\
\text { Caturra }(12.5 \%) \\
\text { Catuaí }(12.5 \%) \\
\text { Caturra }(12.5 \%) \\
\text { Híbrido }(12.5 \%)\end{array}$ & $\begin{array}{l}\text { Washed }(75.0 \%) \\
\text { Natural }(25.0 \%)\end{array}$ & 1452 \\
\hline & Estado de México & 1 & 90.7 & 27.85 & $\begin{array}{c}\text { Caturra }(33.3 \%) \\
\text { Marsellesa }(33.3 \%) \\
\text { Sarchimor }(33.4 \%)\end{array}$ & Natural $(100 \%)$ & 2150 \\
\hline & Guerrero & 4 & 88.55 & 8.18 & $\begin{array}{c}\text { Bourbon }(50.0 \%) \\
\text { Typica }(50.0 \%)\end{array}$ & $\begin{array}{l}\text { Washed }(75.0 \%) \\
\text { Natural }(25.0 \%)\end{array}$ & 1435 \\
\hline & Jalisco & 1 & 90.7 & 69.65 & $\begin{array}{c}\text { Bourbon }(66.6 \%) \\
\text { Caturra }(33.4 \%)\end{array}$ & Washed $(100 \%)$ & 1600 \\
\hline & Oaxaca & 10 & 86.94 & 6.09 & $\begin{array}{c}\text { Mundo Novo }(39.1 \%) \\
\text { Typica }(30.4 \%) \\
\text { Caturra }(17.4 \%) \\
\text { Bourbon }(13.1 \%)\end{array}$ & Washed $(100 \%)$ & 1525 \\
\hline & Veracruz & 9 & 88.26 & 7.36 & $\begin{array}{c}\text { Pacamara }(27.8 \%) \\
\text { Bourbon }(16.7 \%) \\
\text { Caturra }(16.7 \%) \\
\text { Typica }(16.7 \%) \\
\text { Garnica }(11.1 \%) \\
\text { Sarchimor }(5.5 \%) \\
\text { Mundo Novo }(5.5 \%)\end{array}$ & $\begin{array}{l}\text { Washed }(90.0 \%) \\
\text { Natural }(10.0 \%)\end{array}$ & 1363 \\
\hline \multirow{5}{*}{2019} & Chiapas & 6 & 89.64 & 14.63 & $\begin{array}{c}\text { Pache }(37.5 \%) \\
\text { Geisha }(25.0 \%) \\
\text { Bourbon }(25.0 \%) \\
\text { Caturra }(12.5 \%)\end{array}$ & $\begin{array}{l}\text { Washed }(50.0 \%) \\
\text { Natural }(50.0 \%)\end{array}$ & 1555 \\
\hline & Estado de México & 1 & 90.13 & 16.1 & Bourbon $(100 \%)$ & Washed (100\%), & 2150 \\
\hline & Guerrero & 3 & 87.82 & 8 & Bourbon $(100 \%)$ & $\begin{array}{l}\text { Washed }(66.6 \%) \\
\text { Natural }(33.4 \%)\end{array}$ & 1423 \\
\hline & Puebla & 3 & 88.12 & 9.7 & $\begin{array}{c}\text { Marsellesa }(33.3 \%) \\
\text { Garnica }(33.3 \%) \\
\text { Bourbon }(33.4 \%)\end{array}$ & $\begin{array}{c}\text { Washed }(33.3 \%) \\
\text { Natural }(33.3 \%) \\
\text { Doublefermentation } \\
\quad(33.4 \%)\end{array}$ & 1227 \\
\hline & Veracruz & 15 & 88.73 & 7.68 & $\begin{array}{c}\text { Bourbon }(43.5 \%) \\
\text { Pacamara }(12.5 \%) \\
\text { Costa Rica }(12.5 \%) \\
\text { Caturra }(6.3 \%) \\
\text { Typica }(6.3 \%) \\
\text { Garnica }(6.3 \%) \\
\text { Mundo Novo }(6.3 \%) \\
\text { Geisha }(6.3 \%)\end{array}$ & $\begin{array}{l}\text { Washed }(87.5 \%) \\
\text { Honey }(12.5 \%)\end{array}$ & 1314 \\
\hline
\end{tabular}

Source: Processed with data provided by AMECAFE.

${ }^{*}$ Average price at auction (USD. Ib $\left.{ }^{-1}\right)$.

**Percentage of varieties present in the total samples. It does not represent the proportion of mixtures.

${ }^{* * *}$ Several lots were stolen during transport and that's why there's no data.

\section{DISCUSSION}

Geeraert et al. (2019) state that the best notes of coffee (particularly fragrance, aroma, flavor, acidity, and body) are obtained in the best-preserved regions or with the greatest presence of biodiversity, as is the case of Veracruz and Chiapas (Figure 1), because the quality is significantly affected by intensity crop management. This argument favored the protection of coffee associated with its origin (Avelino et al., 2005), which has generated national and 
international recognition through the appellation of origin granted to Veracruz in 2000 and Chiapas in 2003 (Pérez; Pérez, 2012), creating not only value for producers in those regions, but also shaping the strategies for sourcing and distributing the coffee production chain (Conley; Wilson, 2018).

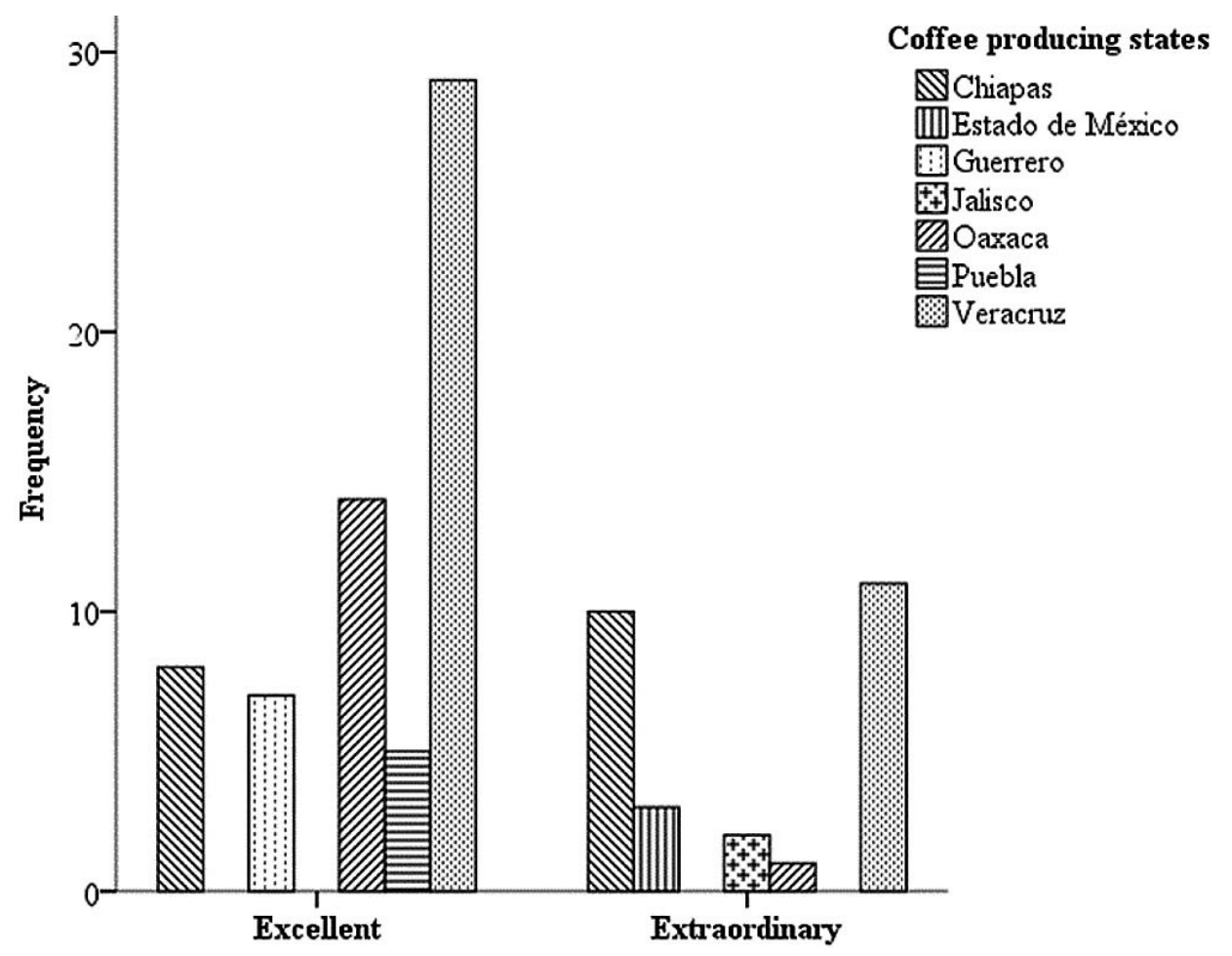

Figure 1: Quality categories related to coffee producing states in Mexico.

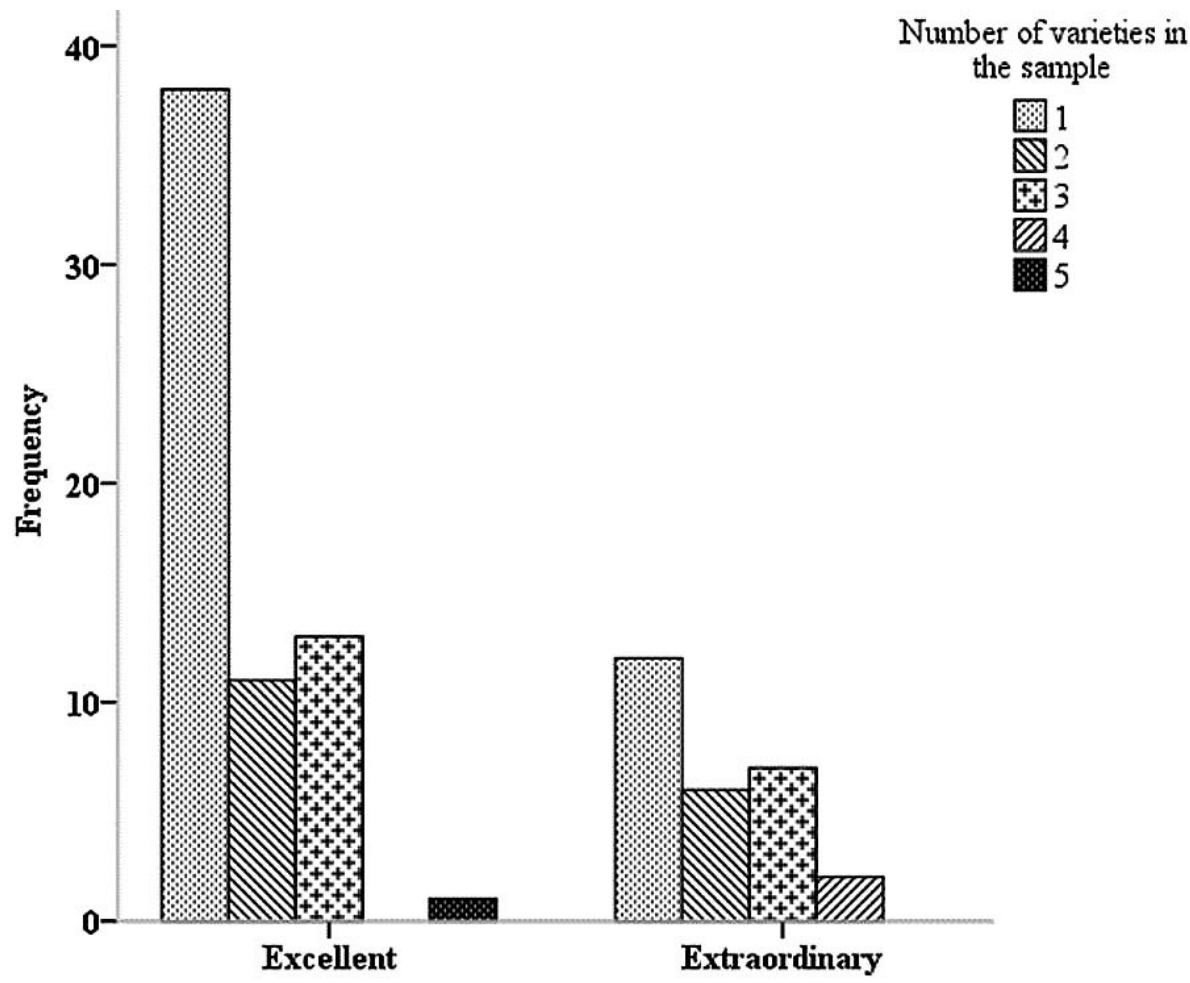

Figure 2: Quality categories related to the number of varieties that make up the coffee samples evaluated in the cup of excellence contest. 


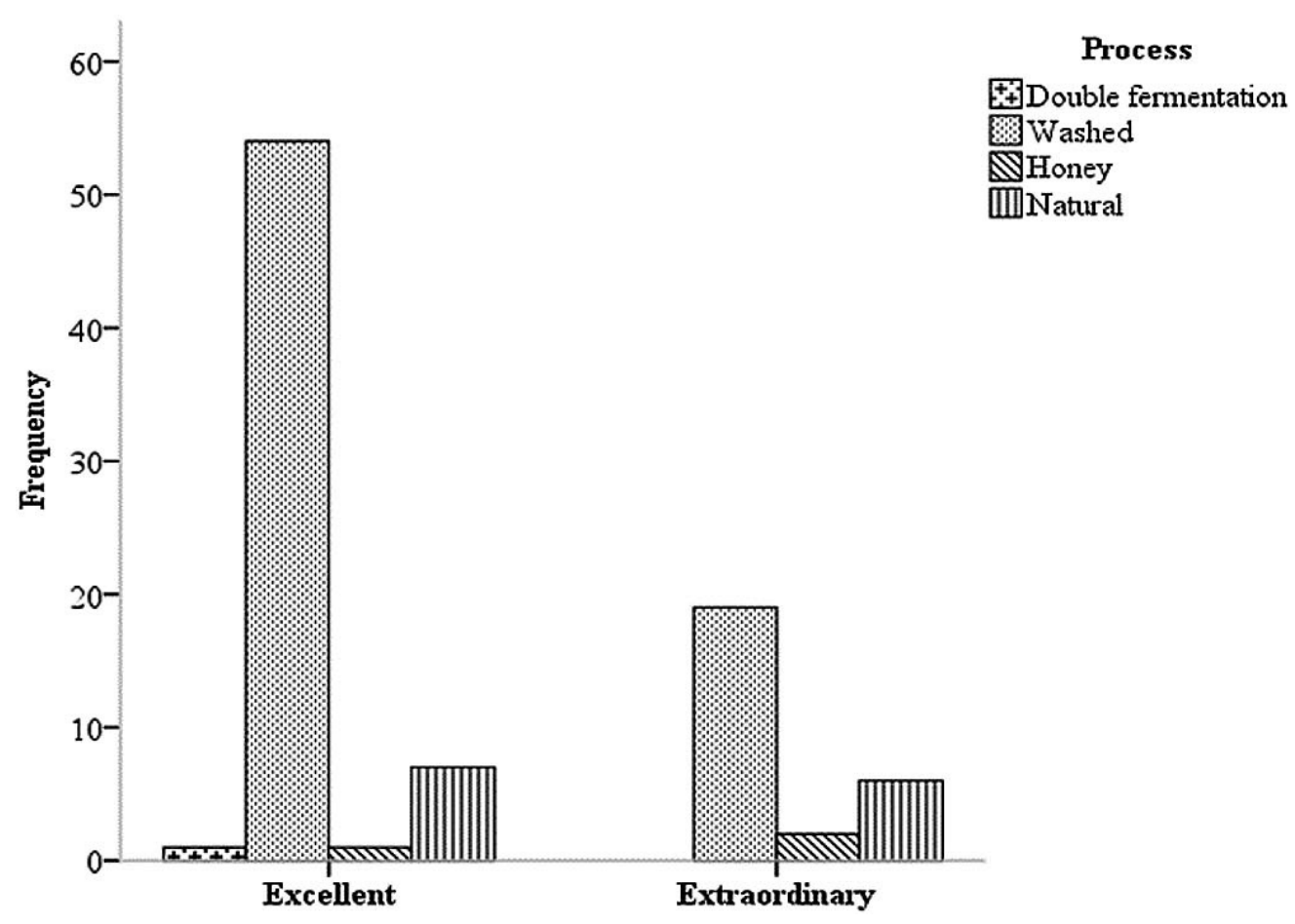

Figure 3: Quality categories related to the type of process.

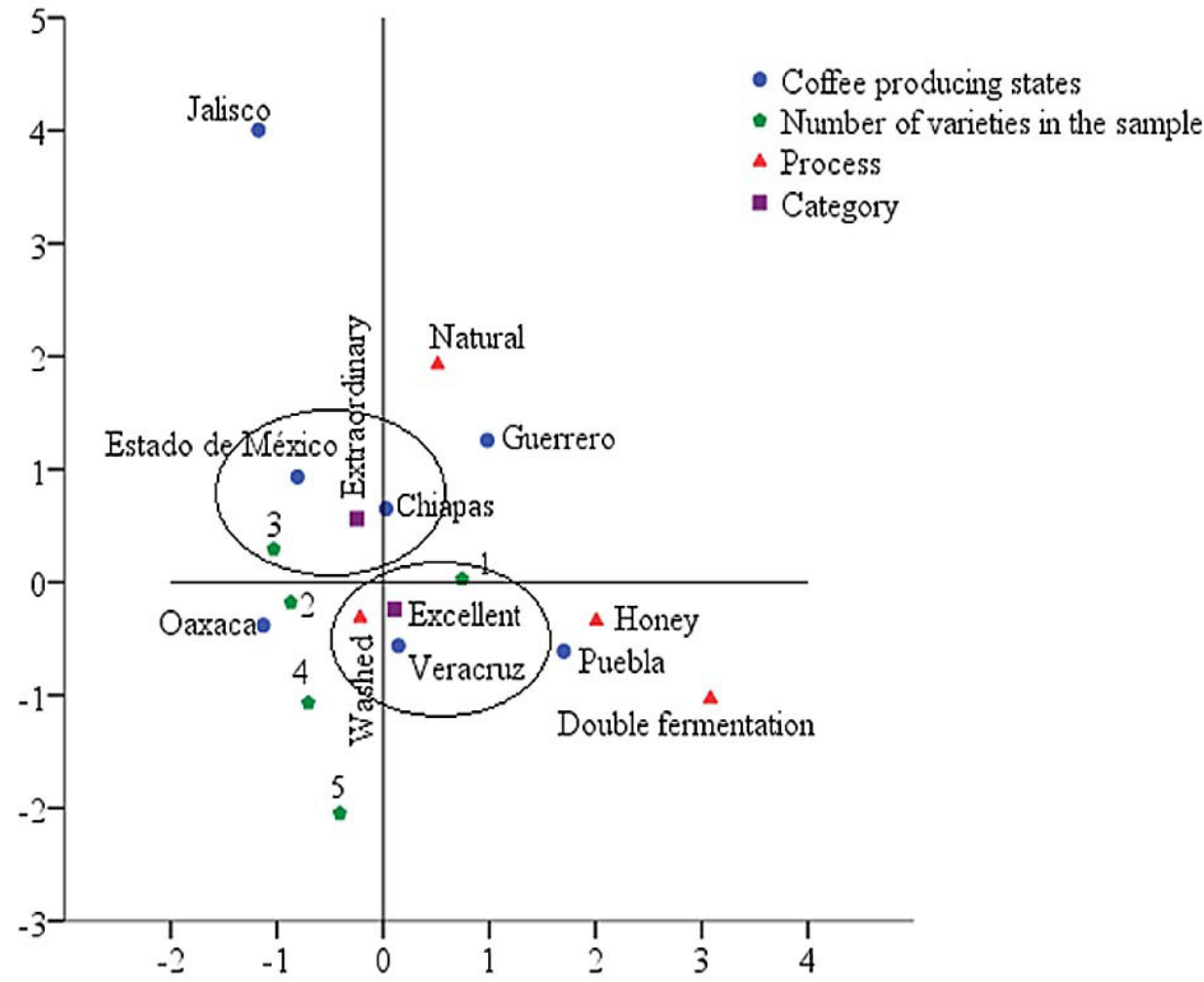

Figure 4: Correspondence analysis between the factors studied related to the score in the cup.

In this context, although in Mexico several options have been promoted and developed to increase the profitability of the crop, such as organic coffee, fair trade, the denomination of coffee origin, and specialty coffees (Pérez-Portilla et al., 2005;
Toledo; Moguel, 2012; Escamilla-Prado et al., 2015), the truth is that few studies have been published to specifically explain the factors related to the quality of coffee (Sánchez et al., 2018; Buendía-Espinoza et al., 2020). However, some important 
aspects have been identified, such as that the increase in the average annual temperature negatively influences the size of the grain, as well as the aroma and acidity of the beverage (Sánchez et al., 2018) and in general in the sensory attributes (Pérez-Portilla et al., 2005). Likewise, the tree coverage of plantations (shading) has a positive effect on the proportion of "planchuela-shaped" grains and on the acidity of the beverage, so that it is possible to combine the crop with trees for forest purposes, without affecting the quality (Pérez-Portilla et al., 2005; Sánchez et al., 2018), although this depends on the conditions of each coffee plantation (Rosas-Arellano et al., 2008; Läderach et al., 2011).

Similarly, it was identified that the origin of the soils is important in the determination of the different flavor profiles (Pérez-Portilla et al., 2005 Läderach et al., 2011; Luna-González et al., 2019) since there is a relationship with nutrition, for example, $\mathrm{Ca}, \mathrm{Mg}$ and $\mathrm{Fe}$ showed an influence on the fragrance of infusion, organic matter and $\mathrm{N}$ showed some effect on taste and B revealed influence in the aftertaste (Rosas-Arellano et al., 2008). Likewise, varieties influence the flavor in cup (particularly those of Arabica type), determining their body, which is key to quality differentiation and therefore market success (Läderach et al., 2011; Figueroa-Hernández; Pérez-Soto; Godínez-Montoya, 2015; Luna-González et al., 2019). In addition, cultural practices (nutrition, pest and disease control), plant age, coffee pruning, shade regulation, weed control, and the production system have been considered to be an important factor in the attributes of the beverage (Rosas-Arellano et al., 2008), so it can be concluded that the quality of coffee in Mexico is the sum of the processes and management carried by the crop, pre, and post-harvest (Läderach et al., 2011; Buendía-Espinoza et al., 2020).

Finally, in Mexico, there are regions with the potential to produce specialty coffee, because of the predominance of Arabic varieties, good temperatures, and vegetal cover (PérezPortilla et al., 2005), since they coincide with the richest and most diverse regions in flora and fauna (Figueroa-Hernández; Pérez-Soto; Godínez-Montoya, 2015). However, these advantages have not been used to improve competitiveness, because, although quality differentiation has gained ground as a new way of competing in the market, it is not yet widespread, since it requires infrastructure, training, and possibly a major change in the attitude of the sector (Pérez-Portilla et al., 2011; Figueroa-Hernández; Pérez-Soto; Godínez-Montoya, 2015).

In terms of altitude, although it is recognized by international markets as a factor that influences the quality of coffee (Bertrand et al., 2006; Bote; Vos, 2017), and which coincides with the perception of various researchers (Taveira et al., 2015; Toledo et al., 2016; Abubakar et al., 2019), the data studied indicate that statistically there is no ratio of altitude to the quality score in the cup $\left(\mathrm{R}^{2}=0.080\right)$, in this regard, Geeraert et al. (2019) indicate that height does not affect the quality of coffee, both in intensive management and in preserved areas. Also, Puerta et al. (2016) did not find a correlation between altitude with the quality of the beverage. However, other authors such as Worku et al. (2018) indicate that the caffeine content and chlorogenic acids (closely related to coffee quality) decreased while the sucrose content increased at higher altitudes, but this effect was only observed in wet processed coffee beans.

The truth is that the data show that the altitude of the winning coffees, is around 1400 m.a.s.l. (1407 m.a.s.l.for excellent and 1496 m.a.s.l. for extraordinary). This coincides with Läderach et al. (2017) which, through models of geographical information, indicates that coffee grows optimally at elevations between 800 and 1400 m.a.s.l. However, with the information obtained it is not possible to find a difference, to determine whether or not this factor has an influence on the quality of coffee, since the data are uniform (all are high grown coffee) so there is no way to see if this is a factor that positively or negatively influences the rate of excellence, since by the data obtained there is no way to contrast them, giving a false positive. Although, in a climate change scenario, ecosystem sensitivity suggests that altitude (along with other factors such as shade and climate) may become important for the production of specialty or high-quality coffee in the future (Worku et al., 2018).

With regard to temperature and precipitation, no relationship was found with the cup score $\left(\mathrm{R}^{2}=0.035\right.$ and $\mathrm{R}^{2}=0.039$ ) as they have no identifiable statistical interactions, however, the attributes of acidity and flavor are linked to climatic conditions, where, for example, higher light and temperature conditions negatively affect the synthesis of various organoleptic-quality precursors in coffee, for example, caffeine, chlorogenic acids and sucrose (Geeraert et al., 2019), which in the face of a global warming scenario by 2050, an increase of $2.5^{\circ} \mathrm{C}$ would modify the current distribution of the crop, which would go from elevations between 800 and 1400 m.a.s.l, to 1200 and 1600 m.a.s.l (Läderach et al., 2017). Likewise, Bunn et al. (2015), suggests that coffee is very sensitive to climate change and that an increase in temperature will reduce its yield. As for the influence of precipitation on the cup score, no reports were found that show a clear relationship between the two elements.

In comparison, the only factors that influence the score are the mix of varieties and the process (chi test value $=$ 4.513). In this sense, the highest score and therefore the best quality (Figure 2) is obtained with the use of a single variety (pure coffee) or the mixture of three (where usually one is around $50 \%$, being mainly of the Arabica coffee type and the others in different amounts, which give it certain notes that positively influence the evaluation, without being able to identify an ideal proportion). Although specific information is scarce, Dos Santos et al. (2018) indicates that the mixture 
of berries harvested in different strata could have an impact on the quality of the beverage by the variety of chemical compounds (for example, isomers of caffeoylquinic), determined by the type and maturity of coffee beans, which might suggest that the mixture between different varieties has a similar effect.

Likewise, Geeraert et al. (2019) note that organoleptic quality may vary, for example, through caffeine content, depending on the genotype of coffee, responses to environmental factors and changes in microclimate, decreased shade levels, and biotechnology (enhanced varieties). It also indicates that varieties of the Arabica type, on their own are the highest quality ones, such as Bourbon, Typica, and Caturra, which are the main varieties used in Mexico (López-García et al., 2016), which were identified as the most used in this study, with $29.3,17.2$ and $15.3 \%$ respectively, which presents highly appreciated sensory characteristics and a high commercial value. Similarly, Pereira et al. (2017) indicate that the cup quality of varieties from the Timor hybrid is not as good. However, Catimores and Sarchimores do not always present quality issues and have sometimes been surprised to win some excellence rate competitions and get high scores (De Melo; Astorga, 2015).

With respect to coffee processing, there are four types in Mexico: natural (the berry is left directly in the sun before removing the coffee beans), washed (the berry is removed, fermented in water for 18 to 24 hours to remove the mucilage, washed, and finally dried), honey (partially removed pulp and mucilage and left to dry the coffee beans) and double fermentation (the coffee beans follow the washing process, but is fermented twice, which generates a higher consumption of water, but a very clean coffee) (Oliveira et al., 2013). The way the coffee beans is processed (wet or dry) determines its characteristic taste and differentiates in quality (Kleinwächter; Selmar, 2010), since the biochemical composition (free amino acids, chlorogenic acids, trigonelline, and sugar), as well as certain attributes, vary substantially (Worku et al., 2018), which generates different scores in sensory assessment (Taveira et al., 2015).

It is observed that unlike honey or natural, which often bring body and fruit flavor to the beverage, by fermentation of the mucilage that remains covering the coffee beans, (but which makes it difficult to predict the final profile of the cup), the coffees processed in wet, are the ones that have the greatest influence on the cup scores (Figure 3), since they have a better aroma (as well as greater acceptance of the consumer) (Worku et al., 2018) a "clean" flavor (since fermented sugars and mucilage have been removed, in such a way that the taste of coffee itself is perceived, if it has been done correctly) highlighting the characteristic profile of a coffee of origin, producing higher score in the "cupping" tests (Abubakar et al., 2019), this because this process produces more acidic attributes and less bitter notes, burnt and woody (PeñuelaMartínez; Zapata-Zapata; Durango-Restrepo, 2018; Abubakar et al., 2019), in addition to allowing greater control over the quality of the final product (Oliveira et al., 2013).

Although in the case of the double fermentation process the category of extraordinary was not reached (which is why it would be advisable not to do so), in the opinion of PeñuelaMartínez; Zapata-Zapata; Durango-Restrepo (2018), through it (controlling fermentation and consequently the production of organic acids and alcohols, esters and ketones) it is possible to modulate the acidity of the beverage, as well as the fragrance and aroma, to create differentiated profiles in order to meet the requirements of special coffees.

Finally, it was observed that there is a dependence between the mix of varieties and process, i.e., both factors and their interactions have an effect on coffee score and quality (Cronbach alpha, average $=0.624$ ). This is consistent with Abubakar et al. (2019) which indicates that they influence the sensory characteristics of the coffee. Similarly, Joët et al. (2010) mention that quality is associated with the intrinsic characteristics of coffee, wet process, and growing conditions. Finally, the multiple correspondence analysis indicates that there are patterns and category groups between quantitative and qualitative factors, showing the relationships of dependence and similarity between them (Figure 4). It is observed that the strongest associations are given for the category of excellent between the state of Veracruz, the washing process in a single variety of coffee and for extraordinary in Chiapas with washing process and one and three varieties. Likewise, the processes: natural, honey, and double fermentation, and the use of 2, 4, or more varieties in a mixture do not contribute to quality scores. This somehow corroborates what has already been discussed individually for each of these factors.

\section{CONCLUSIONS}

The analysis of the factors related to the quality of coffee cup, through "Cup of Excellence" shows that the process and number of varieties used in the coffee mixture have an influence on the score. Of these, the washing method is best suited for coffees with an extraordinary quality profile, as well as the use of a single variety of coffee (particularly Arabica type: Bourbon, Typica, and Caturra). It could also be identified that the environmental and site components, for this case, do not have a decisive effect on the quality of the coffee.

\section{ACKNOWLEDGMENTS}

To the Universidad Veracruzana for the support of the scholarship of assistant National Researcher 2018 project 41504, to AMECAFE for the data provided, as well as the statistical support of Mr. Eliseo García Mendoza. 


\section{REFERENCES}

ABUBAKAR, Y. et al. Effect of varieties and processing practices on the physical and sensory characteristics of Gayo Arabica specialty coffee. IOP Conference series: MaterialsScience and Engineering, 523:012027, 2019.

\section{ASOCIACIÓN MEXICANA DE LA CADENA} PRODUCTIVA DEL CAFÉ - AMECAFE. Convocatoria $8^{\circ}$ Certamen Taza De Excelencia México 2021. 2021. Available in: <https://www.tazadeexcelenciamexico.org/ convocatoria-productores-2021/>. Access in: June, 28, 2021.

AVELINO, J. et al. Effects of slope exposure, altitude and yield on coffee quality in two altitude terroirs of Costa Rica, Orosi and Santa Maria de Dota. Journal of the Science of Food and Agriculture, 85(11):1869-1876, 2005.

BERTRAND, B. et al. Comparison of bean biochemical composition and beverage quality of Arabica hybrids involving Sudanese-Ethiopian origins with traditional varieties at various elevations in Central America. Tree Physiology, 26(9):1239-1248, 2006.

BOTE A. D.; VOS J. Tree management and environmental conditions affect coffee (Coffea arabica L.) bean quality. NJAS Wageningen Journal of Life Science, 83:39-46, 2017.

BRESSANELLO, D. et al. Coffee aroma: Chemometric comparison of the chemical information provided by three different samplings combined with GC-MS to describe the sensory properties in cup. Food Chemistry, 214:218226, 2017.

BUENDÍA-ESPINOZA, J. C. et al. Identificación de elementos discriminatorios para caracterizar el Coffea arabica L. empleando componentes principales. Revista Mexicana de Ciencias Agrícolas, 11(1):1-12, 2020.

BUNN, C. et al. A bitter cup: Climate change profile of global production of Arabica and Robusta coffee. Climatic Change, 129:89-101, 2015.

COMISIÓN NACIONAL DEL AGUA - CONAGUA. Normales Climatológicas por Estado. México, r.19. Available in: < https://smn.conagua.gob.mx/es/ climatologia/informacion-climatologica/normalesclimatologicas-por-estado>. Access in: June, 28, 2021.

CONLEY, J.; WILSON, B. Coffee terroir: Cupping description profiles and their impact upon prices in Central American coffees. GeoJournal, 85:67-79, 2018.

CRAIG, A. P. et al. Mid infrared spectroscopy and chemometrics as tools for the classification of roasted coffees by cup quality. Food Chemistry, 245:1052-1061, 2018.
DE MELO, E. V. F.; ASTORGA, D. C. Prevención y control de la roya del café Manual de buenas prácticas para técnicos y facilitadores. Turrialba, Costa Rica: Centro Agronómico Tropical de Investigación y Enseñanza (CATIE), 2015. 96p. (Serie Técnica Manual Técnico no. 131).

DI DONFRANCESCO, B.; GUTIERREZ, G. N.; CHAMBERS IV, E. Comparison of results from cupping and descriptive Sensory analysis of Colombian brewed coffee. Journal of Sensory Studies, 29(4)301-311, 2014.

DOS SANTOS, S. M. B. et al. From the field to coffee cup: impact of planting design on chlorogenic acid isomers and other compounds in coffee beans and sensory attributes of coffee beverage. European Food Research and Technology, 244(10):1793-1802, 2018.

ESCAMILLA-PRADO, E. et al. Calidad en variedades de café orgánico en tres regiones de México. Revista de Geografía Agrícola, 55:45-55, 2015.

FERIA, M. A. M. Examining the case of green coffee to illustrate the limitations of grading systems/expert tasters in sensory evaluation for quality control. Food Quality and Preference, 13(6):355- 367, 2014.

FIGUEROA-HERNÁNDEZ, E.; PÉREZ-SOTO, F.; GODÍNEZ-MONTOYA, L. La producción y el consumo del café. Spain: ECORFAN, 2015. 170p.

GEERAERT, L. et al. Organoleptic quality of Ethiopian Arabica coffee deteriorates with increasing intensity of coffee forest management. Journal of Environmental Management, 231:282-288, 2019.

GIACALONEA, D. et al. Common roasting defects in coffee: Aroma composition, sensory characterization and consumer perception. Food Quality and Preference, 71:463-474, 2019.

JOËT, T. et al. Influence of environmental factors, wet processing and their interactions on the biochemical composition of green Arabica coffee beans. Food Chemistry. 118(3):693-701, 2010.

KLEINWÄCHTER, M.; SELMAR. D. Influence of drying on the content of sugars in wet processed green Arabica coffees. Food Chemistry, 119 (2):500-504, 2010.

LÄDERACH, P. et al. Climate change adaptation of coffee production in space and time. Climatic Change, 141(1):47-62, 2017.

LÄDERACH, P. et al. Systematic agronomic farm management for improved coffee quality. Field Crops Research, 120(3):321-329, 2011. 
LOPEZ-GARCÍA, F. J. et al. Producción y calidad en variedades de café (Coffea arabica L.) en Veracruz, México. Revista Fitotecnia Mexicana, 39(3):297-304, 2016.

LUNA-GONZÁLEZ, A. et al. Cup quality attributes of Catimors as affected by size and shape of coffee bean (Coffea arabica L.). International Journal of Food Properties, 22 (1):758-767, 2019.

MANSON, R. H.; CONTRERAS, A.; LÓPEZ, F. Estudios de la biodiversidad en cafetales. In: MEHLTRETER, K; GALLINA, S; ORTIZ V. H. Agroecosistemas cafetaleros de Veracruz: Biodiversidad, manejo y conservación. México: Instituto Nacional de Ecología-INE-Semarnat, p. $1-14,2008$.

OLIVEIRA, P. D. et al. Physiological aspects of coffee beans, processed and dried through different methods, associated with sensory quality. Coffee Science, 8(2):203-2011, 2013.

OYOLA, T. S.; TRUJILLO, B. D.; GUTIÉRREZ, G. N. Aplicación del proceso analítico jerárquico AHP para definir la mejor taza en evaluación de cafés especiales. Coffee Science, 12(3):374-380, 2017.

PEÑUELA-MARTÍNEZ, A. E.; ZAPATA-ZAPATA, A. D.; DURANGO-RESTREPO, D. L. Performance of different fermentation methods and the effect on coffee quality (Coffea arabica L.). Coffee Science, 13(4):465-476, 2018.

PEREIRA, L. L. et al. The consistency in the sensory analysis of coffees using Q-graders. European Food Research and Technology, 243(9):1545-1554, 2017.

PÉREZ, A. P.; PÉREZ, T. M. Las denominaciones de origen del café mexicano y sus cuestionamientos como modelo de desarrollo regional. Perspectivas Rurales Nueva Época, 10(19):43-56, 2012.

PÉREZ-PORTILLA, E. et al. Determinación de las subdenominaciones de origen del Café Veracruz (estudio preliminar). Revista de Geografía Agrícola, 35: 23-38, 2005.

PÉREZ-PORTILLA, E. et al. Estrategia de mejoramiento de la producción cafetalera de la organización Campesinos Ecológicos de la Sierra Madre de Chiapas: Caracterización de la bebida de café. Revista de Geografía Agrícola, 46-47:7-18, 2011.

PUERTA Q. G. I. et al. Diagnóstico de la calidad del café según altitud suelos y beneficio en varias regiones de Colombia. Revista Cenicafé, 67(2):15-51, 2016.

ROCHA, B. M.; COQUEIRO, A.; VALDERRAMA, P. Brazilian coffee blends: A simple and fast method by near-infrared spectroscopy for the determination of the sensory attributes elicited in professional coffee cupping. Journal of Food Science, 84(6):1247-1255, 2019.
ROSAS-ARELLANO, J. et al. Relación de los nutrimentos del suelo con las características físicas y sensoriales del café orgánico. Terra Latinoamericana, 26(4):375384, 2008.

SÁNCHEZ, H. S. et al. Calidad del café (Coffea arabica L.) en dos sistemas agroforestales en el centro de Veracruz, México. Agro Productividad, 11(4):80-86, 2018.

SERVICIO DE INFORMACIÓN AGROALIMENTARIA Y PESQUERA - SIAP. Secretaría de agricultura, ganadería, desarrollo rural, pesca y alimentación. México, 2018. Available in: <https://nube.siap.gob.mx/ cierreagricola/>. Access in: June, 30, 2021.

SPECIALTY COFFEE ASSOCIATION OF AMERICA SCAA. SCAA Protocols - Cupping Specialty Coffee. 2015. Available in: $<$ https://www.scaa.org/PDF/resources/ cupping-protocols.pdf $>$. Access in: June, 28, 2021.

SUNARHARUM, W. B.; WILLIAMS, D. J.; SMYTH, H. E. Complexity of coffee flavor: A compositional and sensory perspective. Food research international, 62:315-325, 2014.

TAVEIRA, J. H. S. da. et al. Post-harvest effects on beverage quality and physiological performance of coffee beans.

African Journal of Agricultural Research, 10(12):14571466, 2015.

TOLEDO, P. R. A. B. et al. Relationship between the different aspects related to coffee quality and their volatile compounds. Comprehensive Reviews in Food Science and Food Safety, 15 (4):705-719, 2016.

TOLEDO, V. M.; MOGUEL, P. Coffee and sustainability: The multiple values of traditional shaded coffee. Journal of Sustainable Agriculture, 36(3):353-377, 2012.

TOLESSA, K. et al. Prediction of specialty coffee cup quality based on near infrared spectra of green coffee beans. Talanta, 150:367-374, 2016.

UFER, D.; LIN, W.; ORTEGA, D. L. Personality traits and preferences for specialty coffee: Results from a coffee shop field experiment. Food Research International, 125:108504, 2019.

VAAST, P. et al. Fruit thinning and shade improve bean characteristics and beverage quality of coffee (Coffea arabica L.) under optimal conditions. Journal of the Science of Food and Agriculture, 86(2):197-204, 2006.

WORKU, M. et al. Effect of altitude on biochemical composition and quality of green arabica coffee beans can be affected by shade and postharvest processing method. Food Research International, 105:278-285, 2018. 